\title{
POLA PERSEBARAN PERUMAHAN MENURUT KELOMPOK ETNIS DI KELURAHAN KUTO BATU, KOTA PALEMBANG
}

\author{
Eni Heldayani', Su Ritohardoyo ${ }^{2}$, dan Dyah Widiyastuti ${ }^{3}$
}

Fakultas Geografi,Universitas Gadjah Mada, Yogyakarta, Indonesia ${ }^{1,2,3}$

eniheldayanigeo@gmail.com

Diterima : Juni 2014; Direvisi: Agustus 2014.; Dipubikasikan: 31 Maret 2014

\begin{abstract}
ABSTRAK Heterogenitas penduduk secara horisontal ditandai dengan beragamnya kelompok etnis yang menyelenggarakan hidup di perkotaan. Eksistensi kelompok etnis berkaitan dengan eksistensi perumahan. Lokasi dari perumahan menurut kelompok etnis adalah inti dari penelitian ini. Tujuan penelitian pertama adalah mengidentifikasi pola sebaran perumahan menurut kelompok etnis. Tujuan kedua adalah mengetahui faktor-faktor yang mempengaruhi pola sebaran perumahan menurut kelompok etnis. Penelitian ini adalah penelitian kasus. Pengumpulan data primer dilakukan dengan teknik pemetaan partisipatif dan wawancara tokoh kunci yang ditentukan menggunakan teknik bola salju. Semua data penelitian dianalisis secara kualitatif untuk dapat menjawab pertanyaan penelitian. Hasil penelitian ini menunjukkan beberapa temuan-temuan yaitu: (1) sebaran perumahan etnis Tionghoa adalah berpola teratur dimana tersusun berderet mengikuti geometri jaringan jalan sehingga pola bentuk sebarannya seperti huruf L dan I. Sebaran perumahan etnis Arab adalah berpola tidak teratur. Susunan bangunan perumahan etnis Arab memiliki kesan semu yang seolah-olah tersusun memusat pada obyek/fasilitas umum seperti lapangan, tempat ibadah, bahkan situs kuna (Rumah Batu). Geometri dari susunan bangunan perumahan berhadap-hadapan dan memusat pada obyek khusus menciptakan pola bentuk seperti huruf U dan I. Sebaran perumahan etnis Jawa adalah berpola tidak teratur. Memusat di sekitar lokasi tempat bekerja dengan akses harga rumah yang relatif murah (dekat sungai). Orientasi dari bangunan perumahan etnis Jawa adalah membelakangi sungai sehingga bentuk dari perumahan mereka terkesan menciptakan pola bentuk seperti huruf S dan I. Sebaran dari perumahan etnis Melayu adalah berpola tidak teratur. Susunan bangunan perumahan pada tiap zona bervariasi sehingga memiliki kesan kombinasi/ percampuran dari susunan berderet dan memusat. Orientasi bangunan perumahan menghadap ke arah daratan. Geometri dari bentuk bangunan perumahannya pada tiap zona juga teridentifikasi sebagai percampuran antara bentuk L, I, U, dan S. (2) faktor-faktor yang mempengaruhi pola sebaran perumahan menurut kelompok etnis di Kelurahan Kuto Batu antara lain adalah kecenderungan dalam mempertimbangkan lokasi perumahan berdasarkan kriteria dari karakter tempat tinggal, karakter lingkungan tempat tinggal, interaksi sosial serta kebijakan publik yang berlaku di lingkungan tersebut. Karakter tempat tinggal berkaitan dengan fungsi rumah dan hak kepemilikan rumah. Karakter lingkungan tempat tinggal berkaitan dengan jenis matapencaharian, kedekatan fungsi pelayanan, jaringan transportasi, dan keseragaman penduduk dari daerah asal. Kriteria interaksi sosial berhubungan dengan asmiliasi perekonomian, sosial, budaya, dan kuliner. Kriteria kebijkan publik berkaitan dengan kemudahan untuk mengakses tempat tinggal di Kuto Batu. Pengamatan terhadap pola sebaran perumahan menurut kelompok etnis berserta peluang atas faktor-faktor yang mempengaruhinya merupakan instrumen kunci dalam manajemen perkotaan dengan komposisi masyarakat yang plural.
\end{abstract}

Kata kunci: heterogenitas penduduk secara horizontal; pola persebaran perumahan etnis; pemetaan partisipatif.

ABSTRACT Horizontal heterogenety of the population is characterized by the diversity of ethnic groups living in urban organizing. The ethnic groups existing are regarded to the existence of housing. The location of the housing according to ethnic group is the core of this study. The first research goal is to identify the pattern of distribution of housing according to ethnic groups. The second objective was to determine the factors that affect the distribution pattern of the housing according to ethnic groups. This research is a case study. Primary data collection was done by using participatory mapping and interview key figures are determined using the snowball technique. All data were analyzed qualitatively in order to answer the research questions. The results showed some of the findings: (1) the distribution of ethnic Chinese housing is arranged in a row in which the irregular pattern followed the road network geometry so that the pattern of spreading shape like the letter $L$ and I. Distribution of ethnic Arab housing is patterned irregular. The composition of the building housing the Arabs have the impression that as if pseudo arranged centered on the object / public facilities such as courts, places of worship, even sites kuna (Stone House). The geometry of the arrangement of a residential building, face to face and focuses 
on specific objects creates a pattern shape like the letter U and I. Spread Javanese housing is patterned irregular. The Centered around the location where work with access to the relatively cheap price of the house (near the river). The orientation of the building housing the Javanese is turned rivers that form of housing they seem creating a pattern shape like the letter $S$ and I. Distribution of housing Malays is patterned irregular. The composition of residential buildings in each zone varies so has the impression of a combination / mixing of the orders lined up and centered. Orientation residential building is facing toward the mainland. The geometry of the shape of the building housing in each zone is also identified as a mixture of forms of $L, I, U$, and $S$. (2) the factors that affect the distribution pattern of the housing according to ethnic groups in Kuto Batu Village, among others, is the tendency to consider the location of housing based the criteria of residence of character, the character of the neighborhood, the social interaction as well as public policies in force in the neighborhood. The residence character with regard to the function of the home and home ownership rights. The neighbourhood character with regard to the type of livelihood, the proximity of the service function, the transport network, and the uniformity of the population of the area of origin. Criteria related to social interaction assimilation economic, social, cultural, and culinary. Criteria for public development policy with regard to ease of access to places to stay in Kuto Batu. Observation of the housing distribution pattern according to ethnic groups along with the opportunities of the factors that influence is a key instrument in the management of urban composition pluralistic society.

Keywords: horizontal heterogeneity of the population; ethnic housing distribution pattern; participatory mapping.

\section{PENDAHULUAN}

Isu heterogenitas penduduk terutama secara horisontal, menjadi perhatian ahli perkotaan pada abad ini. Beragam etnis masyarakat yang menghuni kota masing-masing baik yang berasal dari kelompok pribumi, pendatang pribumi, dan pendatang asing membutuhkan tempat tinggal di ruang perkotaan (CLIP, 2007). Penentuan tempat tinggal untuk pertama kali bagi kelompok etnis merupakan tahapan awal yang cukup berat. Tidak semua kelompok etnis dapat mandiri dan bebas dalam menentukan tempat tinggal, beberapa cenderung mencari lingkungan yang setara dengan budayanya (Massey \& Denton, 1988; $\underline{\text { Saltman, }}$ 1991).

Reardon dan O'Sullvivan (2004) menemukan bahwa sebaran perumahan etnis erat kaitannya dengan lokasi relatif dari masing-masing tempat tinggal mereka. Ekspresi yang dimunculkan dari lokasi tempat tinggal etnis menciptakan suatu dimensi spasial. Hasil penelitian Reardon dan O'Sullvivan (2004) menemukan dua (2) dimensi spasial dari sebaran perumahan etnis yaitu dimensi pengelompokan/kemerataan dan dimensi keterisolasian/ketermunculan. Terbentuknya variasi pola tersebut adalah konsekuensi dari adanya perbedaan lokasi tempat tinggal antara kelompok etnis minor dengan mayor. Selain itu, faktor sejarah, kebijakan politik, restrukturisasi perekonomian dan konsep/sistem negara juga turut memberikan pengaruh terhadap ekspresi keruangan yang terbentuk (Deurloo \& Musterd, 2001).

Sebaran kelompok-kelompok rumah ditinjau dari eksistensi kelompok etnis menjadi kajian yang menarik beberapa dekade ini. Beberapa hasil penelitian menangkap keunikan ekspresi keruangan dari beberapa kelompok etnis yang mencoba mempertahankan identitas budayanya secara spasial, baik di perkotaan maupun di perdesaan. Wacana keberadaan etnis dan karakteristik spasialnya memberikan konsekuensi baik pada tata ruang dan dinamika perkembangan perkotaan. Wacana tersebut juga dapat dianggap sebagai indikator penting bagi negara dalam hal menerima atau menghadapi isu tersebut. Musterd (2011) menyatakan bahwa adanya kelompok-kelompok rumah yang membentuk suatu area berdasar kelompok etnis tertentu di perkotaan memberikan konsekuensi adanya gejala pemisahan perumahan etnis (ethnic housing segregation). Salah satu konsekuensi dari gejala tersebut adalah fenomena kriminalitas yang terjadi di daerah Ghetto, Amerika akibat ketimpangan kondisi sosial ekonomi antara etnis mayoritas dan minoritas, sedangkan di Eropa terjadi kekakuan mobilitas sosial oleh kelompok etnis tertentu dalam hal mengakses perumahan dan fasilitas umum di perkotaan.

Terkait dengan gejala tersebut, CLIP (2007) menyatakan bahwa isu kontroversi terbentuknya kelompok-kelompok rumah berdasarkan kelompok etnis maupun strata sosial di perkotaan perlu diperhatikan baik oleh pembuat kebijakan dan pelaku kebijakan dimana didalamnya dibahas apakah isu tersebut adalah kendala atau sebaliknya memfasilitasi intergrasi penduduk dan migran di perkotaan. Pada penelitian ini peneliti tertarik untuk mengangkat isu tentang heterogenitas secara horisontal dengan mempelajari pola sebaran lokasi perumahan menurut kelompok etnis. Tujuan dari penelitian ini adalah mempelajari bagaimana pola persebaran perumahan etnis dan menganalisi factor-faktor yang 
mempengaruhi terbentuknya pola persebaran perumahan dari masing-masing kelompok etnis. Harapannya hasil penelitian dapat menjadi langkah awal untuk memudahkan dalam manajemen perkotaan dengan komposisi masyarakat plural, terutama terkait perumahan mereka.

\section{METODE PENELITIAN}

Dalam rangka memahami fenomena heterogenitas penduduk secara horisontal di perkotaan maka lokasi pengamatan yang relevan pada penelitian ini dilakukan di Kelurahan Kuto Batu, Kota Palembang. Kelurahan Kuto Batu merupakan bagian dari urban heritage dan berdasar RTRW Kota Palembang tahun 2012-2032 merupakan Kawasan Strategis Sosial Budaya khususnya Kawasan Tepian Sungai Musi. Lokasi Kuto Batu memiliki kedekatan dengan simbol penting bagi perekonomian Kota Palembang yakni berada di antara Sungai Musi, Pelabuhan Bom Baru dan Pasar 16. Keberadaan tiga simbol tersebut memicu terjadinya interaksi antara kelompok etnis pribumi dan kelompok etnis pendatang.

Pengumpulan data penelitian dilakukan dengan pemetaan partisipatif. Pemetaan partisipatif adalah suatu metode pemetaan yang menempatkan masyarakat sebagai tokoh kunci dalam kegiatan pemetaan. Tokoh kunci pada penelitian ini adalah masyarakat Kuto Batu khususnya ketua Rukun Tetangga (RT). Kecenderungan memilih partisipan yang berasal dari Ketua RT didasari asumsi bahwa sejatinya setiap Ketua RT memiliki informasi terkait komposisi warga multi-etnis yang ada di masing-masing wilayah binaannya. Selain pemetaan partisipatif, dilakukan juga kegiatan wawancara semi terstruktur. Penentuan Informan dalam kegiatan wawancara dilakukan dengan teknik bola salju (snowball sampling). Sifat dari teknik sampel ini adalah informasi yang berantai. Adapun kriteria dari informan dalam penelitian ini tidak dibatasi oleh kriteria khusus, informan bersifat terbuka, dan terutama informan adalah masyarakat di lingkungan Kuto Batu.

Pada tujuan pertama untuk menghasilkan peta sebaran perumahan etnis tahapan yang dilakukan adalah 1) data hasil kegiatan pemetaan partisipatif diinterpretasi untuk menghasilkan peta sebaran perumahan menurut kelompok etnis. Interpretasi dilakukan dengan mengabstraksi lokasi perumahan menurut etnis penghuni ke dalam simbol area, 2) hasil abstraksi dikelompokkan dengan memperhatikan variasi dari sebarannya. Variasi sebaran dikenali dengan kriteria-kriteria khusus agar tidak menghasilkan informasi yang subjektif, dan 3) menginterpretasi dan menjawab pertanyaan geografis secara runtut terkait sebaran, pola, dan variasi yang muncul dari objek kajian.

Pada tujuan kedua, pengolahan data dilakukan dengan 1) reduksi data yakni merangkum, memilih hal-hal yang pokok, memfokuskan pada hal-hal yang penting, dicari tema dan polanya. 2) penyajian data yakni menampilkan data dalam bentuk uraian singkat dan dipetakan, dan 3) penarikan kesimpulan atau verifikasi dimana masih bersifat sementara, dan dapat berubah bila tidak ditemukan bukti-bukti yang kuat yang mendukung pada tahap pengumpulan data berikutnya. Setelah dilakukan pengolahan data selanjutnya dilakukan triangulasi. Triangulasi data didasarkan dari hasil kegiatan wawancara, kegiatan pemetaan partisipatif, pengamatan lapangan, dan dokumen pendukung.

Analisis data dilakukan dengan pendekatan keruangan dimana fokusnya adalah analisis pola keruangan. Analisis ini memperhatikan hubungan yang erat antara bentuk dan sifat dari persebaran perumahan menurut kelompok etnis di Kuto Batu. Adapun hal yang diidentifikasi dari hubungan tersebut adalah lokasi, geometri, susunan, dan orientasi dari area perumahan menurut kelompok etnis. Selain itu, untuk penelaahan faktor yang berpengaruh, peneliti menggunakan cara analisis deskriptif kualitatif. Hal terpenting dari kegiatan analisis ini adalah cross check data yang berasal dari informan kepada informan lain dengan tujuan agar meminimalisir kesalahan informasi yang didapat.

\section{HASIL DAN PEMBAHASAN}

Dalam rangka memudahkan identifikasi sebaran dan pola sebaran perumahan menurut kelompok etnis di Kuto Batu maka peneliti membagi menjadi tiga (3) zona observasi yaitu zona utara, zona tengah, dan zona selatan. Adapun dasar dari pembagian zona ini adalah dengan melihat karakteristik perumahan di Kuto Batu. Pada zona selatan yang memiliki kedekatan dengan Sungai Musi dan merupakan lokasi keberadaan situs leluhur arab memiliki kesan perumahan yang masih tradisional. Pada zona ini terdapat bangunan tradisional seperti rumah panggung, rumah batu, ataupun kombinasi dari rumah panggung dan rumah batu. Zona selatan juga menjadi zona untuk kegiatan wisata religi karena terdapat beberapa peninggalan leluhur Arab.

Pada zona tengah, karakteristik perumahan dapat dikatakan transisi dari tradisional menuju ke modern. Beberapa bagunan tradisional ditemui di zona ini dan beberapa bangunan lainnya adalah bangunan tradisional yang telah dibangun ulang menjadi bangunan yang lebih modern. Misalnya rumah toko 
(ruko). Ruko yang ada di zona tengah dapat diklasifikasikan menjadi dua (2), dengan bmendasarkan kepada kondisi bangunannya yaitu ruko tradisional dan ruko modern. Ruko tradsional cenderung berada dekat dengan zona selatan terutama di Jalan Slamet Riyadi, sedangkan ruko modern adalah ruko yang berada di jaringan jalan dari zona tengah yang mengarah ke utara, tepatnya berada di Jalan Dr. M. Isa.

Berbeda dengan zona selatan dan zona tengah, pada zona utara karakteristik perumahan mengekspresikan perumahan yang terbentuk dalam suatu komplek perumahan yang modern dan elit. Lingkungan perumahan yang terwujud di zona utara mengesankan suatu lingkungan yang lebih private karena umumnya dihuni oleh golongan masyarakat yang memiliki pendapatan yang lebih baik dibandingkan dengan masyarakat yang berada di dekat sungai. Kedekatan dengan sungai adalah cara termudah mengidentifikasi perekonomian masyarakat. Semakin lokasi perumahan mereka dekat sungai maka semakin rendah kesejahteraannya, semakin lokasi perumahan menjauhi sungai maka semakin baik kesejahteraannya. Kaitannya memudahkan untuk pembagian zonasi maka peneliti menggunakan batasan fisik jalan dan karakteristik perumahan untuk membagi zona menjadi tiga (3) bagian (lihat Gambar 1).

Pertimbangan tersebut didasarkan dengan melihat arah pergerakan pertumbuhan perumahan di Kuto Batu yang mengarah ke utara. Perkembangan Kuto Batu tidak mengarah ke barat, timur, dan selatan karena terdapat penyimpangan topografis berupa sungai besar dan anak sungai. Awalnya pola perumahan di Kuto Batu adalah linier dengan Sungai Musi, seiring waktu dengan adanya teknologi di bidang transportasi orientasi pembangunan perumahan berubah arah menjadi linier terhadap jalan darat, sehingga pembagian zona ini mempertimbangkan batasan fisik jalan dan karakter perumahan.

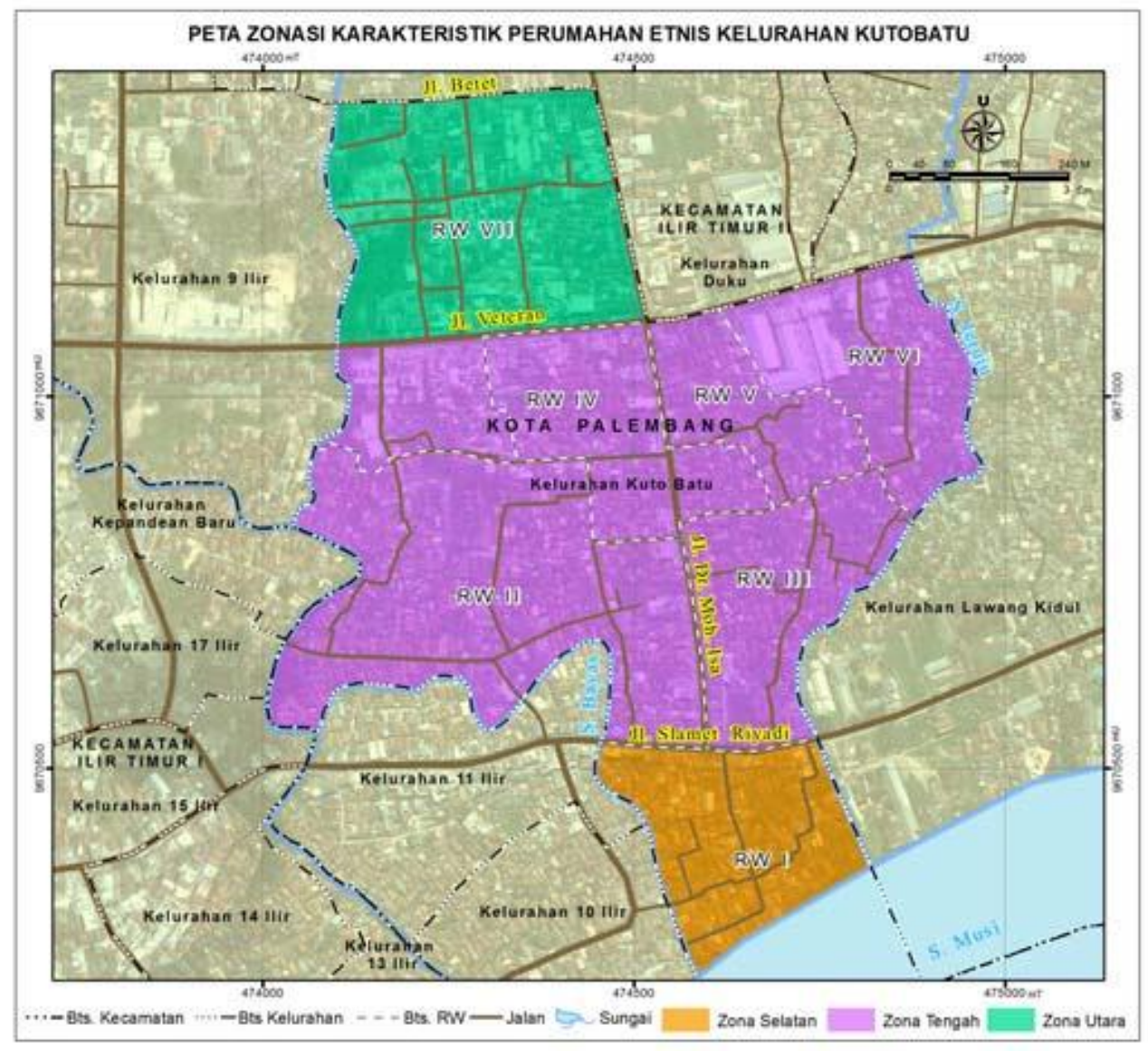

Gambar 1. Zonasi Karakteristik Perumahan di Kuto Batu

Sumber : Olah Data, 2014 
Posisi Kuto Batu sangat strategis menjadi tempat tinggal berbagai kelompok etnis. Kuto Batu terletak di antara Sungai Musi, Pelabuhan Bom Baru, dan Pasar 16. Kondisi inilah yang membuka interaksi yang plural di dalam Kuto Batu. Terkait sebaran lokasi perumahan etnis, hasil dari pemetaan yang dilakukan peneliti menunjukkan bahwa terdapat variasi sebaran dari perumahan kelompok entis yang membentuk suatu pola sebaran.

Pola sebaran dalam penelitian ini dikenali sebagai variasi bentuk pola sebaran perumahan dan variasi sifat pola sebaran perumahan. Pola sebaran perumahan etnis dikenali berdasarkan susunan bangunan, orientasi, geometri, dan letak/lokasi. Kenampakan pola sebaran yang muncul dapat terjadi secara alami maupun buatan manusia. Terkait sebaran lokasi perumahan etnis, hasil
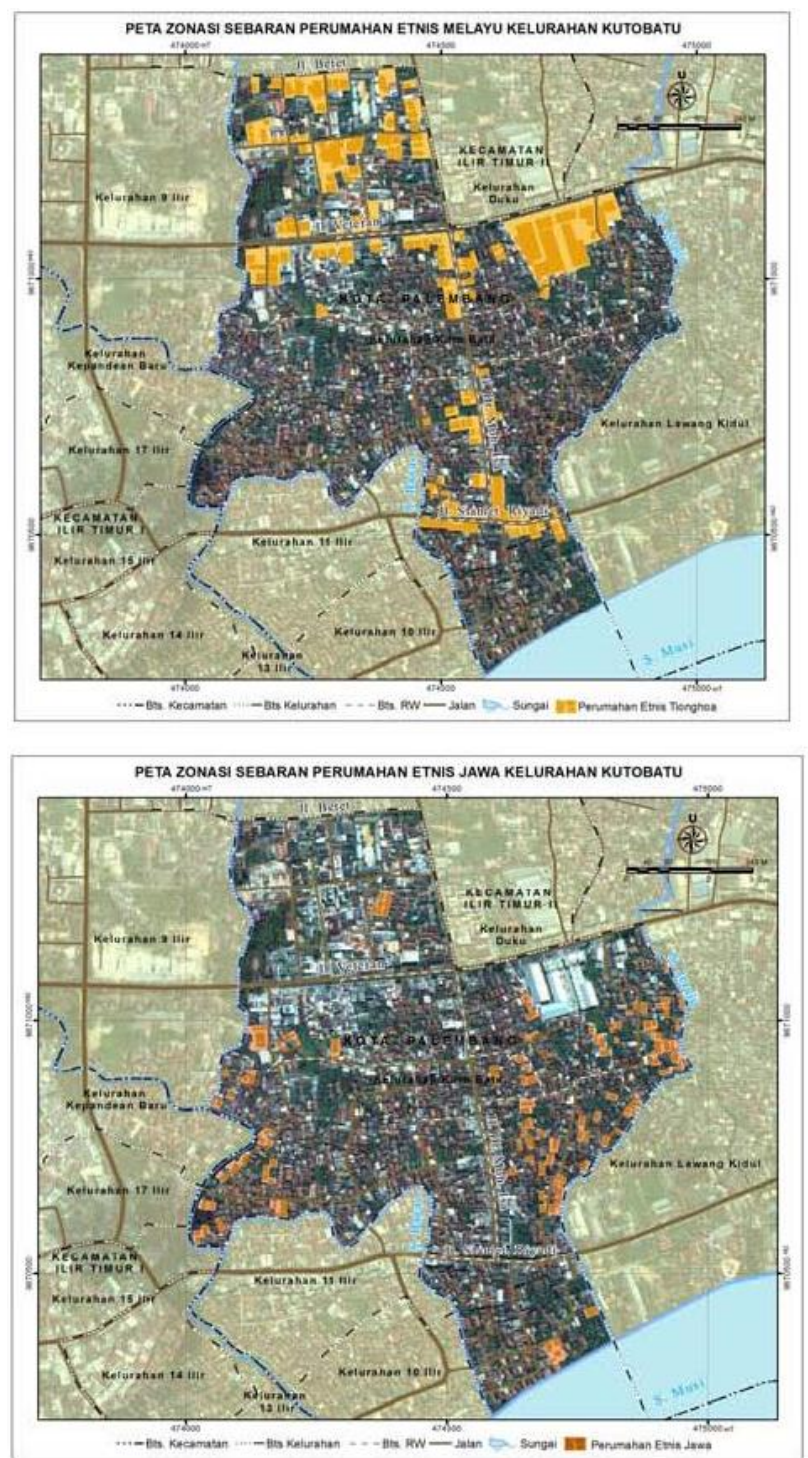

dari pemetaan yang dilakukan peneliti menunjukkan bahwa terdapat variasi sebaran dari perumahan kelompok entis yang membentuk suatu pola sebaran (perhatikan Gambar 2).

Dilihat dari kenampakan yang paling khas dan menonjol yaitu dari susunan, geometri, orientasi, lokasi sebaran serta kepopuleran etnis Tionghoa yang memiliki image sebagai pelopor berdirinya ruko pada kegiatan perdagangan dan jasa di Kuto Batu maka dapat disimpulkan karakter dari pola sebaran perumahannya. Etnis Tionghoa memiliki pola persebaran yang teratur dimana tersusun berderet mengikuti geometri jaringan jalan sehingga pola bentuk sebarannya seperti huruf L dan I.

Gambar 2. Sebaran Perumahan Menurut Kelompok Etnis di Kuto Batu Sumber : Olah Data, 2014 
Berbeda dengan etnis Tionghoa, sebaran perumahan etnis Arab memiliki kesan berpola tidak teratur. Susunan bangunan perumahannya tidak setegas etnis Tionghoa yang tersusun berderet mengikuti geometri jaringan jalan. Susunan bangunan perumahan etnis Arab memiliki kesan semu yang seolah-olah tersusun memusat pada obyek/fasilitas umum seperti lapangan, tempat ibadah, bahkan situs kuna (Rumah Batu). Geometri dari susunan bangunan perumahan yang berhadaphadapan dan memusat pada obyek khusus tersebut menciptakan pola bentuk seperti huruf U dan I. Berkaitan dengan Orientasi/arah, perumahan etnis Arab tidak lagi menghadap ke arah sungai, tetapi sudah berubah menjadi membelakangi sungai. Menjauh dari sungai adalah salah satu cerminan kondisi kesejahteraan masyarakat di lingkungan Kuto Batu. Pandangan yang muncul terkait kehidupan di Kuto Batu dewasa ini adalah semakin menjauhi sungai maka semakin baik pula perekonomian masyarakat.

Sebaran perumahan etnis Jawa berpola tidak teratur. image etnis Jawa sebagai seorang pekerja dan perantau maka dapat disimpulkan bahwa persebaran perumahan mereka adalah berpola tidak teratur, Memusat di sekitar lokasi tempat bekerja dengan akses harga rumah yang relatif murah (dekat sungai), namun demikian orientasi dari bangunan perumahan mereka adalah membelakangi sungai sehingga bentuk dari perumahan mereka terkesan menciptakan pola bentuk seperti huruf S dan I.

Sebaran dari perumahan etnis Melayu adalah berpola tidak teratur. Kenampakan dari susunan bangunan perumahan etnis ini pada tiap zona sangat bervariasi sehingga dapat dikatakan susunan bangunannya adalah kombinasi/ percampuran dari susunan berderet dan memusat. Hampir disetiap zona perumahan dapat ditemui etnis Melayu dimana orientasi/ arah bangunan perumahannya adalah menghadap ke arah daratan. Geometri dari bentuk bangunan perumahannya pada tiap zona juga teridentifikasi sebagai percampuran antara bentuk L, I, $\mathrm{U}$, dan S. Berikut disajikan dalam bentuk tabel 1 terkait pola sebaran dari masing-masing kelompok etnis di Kuto Batu.

Temuan pada penelitian ini menunjukkan adanya variasi pola sebaran perumahan menurut kelompok etnis. Variasi sebaran ini membentuk suatu pola yang khas. Perumahan Etnis Tionghoa adalah perumahan etnis yang memiliki sebaran lebih teratur dibandingkan dengan perumahan etnis Melayu Palembang, Jawa, dan Arab. Dilihat dari pemilihan lokasinya, etnis Tionghoa memiliki modus khusus di bidang perekonomian dengan menempatkan diri pada area strategis di Kuto
Batu. Etnis Jawa adalah etnis yang menujukkan sifat adaptif terhadap lingkungan baru. Etnis Arab terkesan selalu hidup berdampingan dengan sesama kelompoknya. Etnis Melayu Palembang sebagai etnis pribumi tidak menujukkan suatu pola khusus, pola sebaran perumahan mereka lebih menyebar dan merata.

Memahami faktor-faktor yang berpengaruh terhadap pola sebaran dapat dilakukan dengan berbagai pendekatan. Pada penelitian ini fokus peneliti terbatas hanya dengan memperhatikan kecenderungan terhadap pertimbangan lokasi. Peneliti merujuk pada konsep Galster (1987) tentang investasi perumahan. Memahami pertimbangan lokasi dari kelompok etnis dapat menjelaskan eksistensi mereka secara sederhana. Kecenderungan atau pertimbangan kelompok etnis di identifikasi dengan melihat karakter dari tempat tinggal, karakter lingkungan tempat tinggal, karakter interaksi sosial di lingkungan tempat tinggal serta kebijakan publik yang berlaku di lingkungan tempat tinggal. variabel-variabel tersebut setidaknya dapat dijadikan pedoman mengevaluasi pilihan lingkungan tempat tinggal dari kelompok etnis. Hasil dari evaluasi tersebut dapat menjadi dasar penjelas terbentuknya variasi sebaran perumahan etnis yaitu dengan memperhatikan pola yang terbentuk seperti pola sebaran yang teratur atau tidak teratur (lihat Gambar 3).

Karakteristik tempat tinggal adalah kriteria yang dipertimbangkan terhadap kondisi tempat tinggal yang berkaitan dengan tujuan dan kemampuan kelompok etnis untuk mengakses tempat tinggal tersebut. Beberapa dari kelompok etnis tidak hanya memilih lokasi untuk sebagai tempat tinggal, tetapi ada yang mencari nilai strategis lokasi karena tuntutan aktivitas ekonomi, sehingga fungsi dari tempat tinggal mereka menjadi ganda yakni sebagai tempat tinggal dan sebagai toko. Ketika pilihan fungsi dari rumah mereka tidak hanya sebagai tempat tinggal tetapi mereka juga menjadikan rumah sebagai toko maka mereka akan terkonsentrasi di bagian tengah Kuto Batu terutama di sepanjang jalan Dr. M. Isa, jalan Perintis KemerdekaanVeteran, dan Jalan Slamet Riyadi. Bagian tengah Kuto Batu merupakan area strategis pusat kegiatan karena terdapat Pasar Kuto dan pusat pemerintahan.

Sebaliknya apabila pilihan dari kelompok etnis tidak mempertimbangkan fungsi rumah ganda maka kecenderungan sebaran lokasi perumahan mereka acak atau tidak terkonsentrasi pada bagian tengah terutama di sepanjang jaringan jalan utama. Selain fungsi rumah, pertimbangan tempat tinggal etnis juga dapat dilihat berdasarkan kepemilikan rumah. Etnis Jawa sering ditemui berada di lokasi-lokasi dekat sungai dan pabrik 
dengan status sebagai penyewa. Secara umum harga dari sewa rumah yang dekat dengan sungai lebih murah dibandingkan dengan rumah yang terletak di darat. Arab yang secara peradaban sangat dekat dengan Kuto Batu mempunyai hak kepemilikan rumah yang unik dibandingkan dengan etnis lain. Umumnya perumahan Arab di Kuto Batu merupakan warisan dari leluhurnya, sehingga hak kepemilikan rumah mereka adalah hak waris. Rumah waris dari etnis Arab cenderung mendominasi berada di bagian selatan Kuto Batu.

Karakteristik lingkungan tempat tinggal adalah kriteria yang dipertimbangkan terhadap kondisi lingkungan tempat tinggal yang berkaitan dengan tujuan dan kemampuan kelompok etnis untuk mengakses tempat tinggal tersebut. Jenis matapencaharian masing-masing kelompok etnis di Kuto Batu menunjukkan variasi yang khas. Pekerjaan sebagai ulama, guru dan pekerja seni banyak diminati oleh etnis Melayu dan etnis Arab, pekerjaan di bidang perdagangan diminati oleh etnis Arab, etnis Melayu, dan etnis Tionghoa, sementara etnis Jawa lebih memilih untuk tidak bersaing di bidang perdagangan, mereka bekerja sebagai buruh baik buruh cuci maupun buruh kasar dan penjaga toko. Oleh karena itu, dari jenis mata pencaharian dari masing-masing kelompok etnis dapat di identifikasi terkait kemampuan mereka untuk mengakses lokasi perumahan berdasarkan kemampuan ekonominya. Secara umum, lingkungan perumahan yang modern lebih banyak di akses oleh etnis Tionghoa sedangkan lingkungan perumahan yang tradisional banyak diakses oleh etnis Jawa. Jawa sebagai pendatang yang mencari kehidupan yang lebih baik kaitannya dengan rumah banyak yang berstatus sebagai penyewa. Berbeda dengan Jawa dan Tionghoa, Arab dan Melayu lebih lebih fleksibel dalam mengakses lokasi-lokasi di Kuto Batu baik pada zona lingkungan perumahan tradisional sampai modern. Selain kondisi perekonomian, kelompok etnis juga mencari lingkungan tempat tinggal yang terdapat kerabat atau teman dari sesama kelompoknya.

Tabel 1. Pola Sebaran Perumahan Menurut Kelompok Etnis di Kuto Batu

\begin{tabular}{|c|c|c|c|c|}
\hline $\begin{array}{c}\text { Kelompok Etnis } \\
\text { Indikator }\end{array}$ & Tionghoa & Arab & Jawa & Melayu Palembang \\
\hline Sebaran & Teratur & Tidak Teratur & Tidak Teratur & Tidak Teratur \\
\hline Susunan & $\begin{array}{l}\text { Berderet linier } \\
\text { mengikuti bentuk } \\
\text { jaringan jalan }\end{array}$ & $\begin{array}{l}\text { Memusat pada obyek } \\
\text { khusus seperti } \\
\text { lapangan, tempat } \\
\text { ibadah, dan situs kuna }\end{array}$ & $\begin{array}{l}\text { Memusat di sekitar } \\
\text { lokasi tempat bekerja } \\
\text { dengan akses harga } \\
\text { rumah yang relatif } \\
\text { murah }\end{array}$ & $\begin{array}{l}\text { Kombinasi/ } \\
\text { percampuran susunan } \\
\text { berderet dan memusat. } \\
\text { variasi susunan } \\
\text { bangunan beragam. }\end{array}$ \\
\hline Orientasi/Arah & $\begin{array}{l}\text { Menghadap ke arah } \\
\text { daratan (khususnya } \\
\text { jaringan jalan } \\
\text { utama) }\end{array}$ & $\begin{array}{l}\text { Menghadap ke arah } \\
\text { daratan dan } \\
\text { membelakangi Sungai }\end{array}$ & $\begin{array}{l}\text { Menghadap ke arah } \\
\text { daratan dan } \\
\text { membelakangi } \\
\text { Sungai }\end{array}$ & $\begin{array}{l}\text { Menghadap ke arah } \\
\text { daratan dan } \\
\text { membelakangi Sungai }\end{array}$ \\
\hline Geometri & Bentuk L dan I & Bentuk U dan I & Bentuk S dan I & $\begin{array}{l}\text { Kombinasi/ } \\
\text { percampuran bentuk L, } \\
\text { I, U, dan S }\end{array}$ \\
\hline Fungsi & $\begin{array}{l}\text { Rumah tinggal dan } \\
\text { Ruko }\end{array}$ & $\begin{array}{l}\text { Rumah tinggal dan } \\
\text { Ruko }\end{array}$ & Rumah tinggal & Rumah tinggal dan Ruko \\
\hline $\begin{array}{l}\text { Jenis Mata } \\
\text { Pencaharian }\end{array}$ & $\begin{array}{l}\text { Pedagang sembako, } \\
\text { kelontong, dan } \\
\text { bahan bangunan } \\
\text { /material, pemilik } \\
\text { industri, sablon dan } \\
\text { percetakan }\end{array}$ & $\begin{array}{l}\text { Ulama, guru, dan } \\
\text { Pedagang kain, } \\
\text { Pedagang parfum, } \\
\text { kuliner/makanan, }\end{array}$ & $\begin{array}{l}\text { buruh cuci, buruh } \\
\text { kasar, penjaga toko }\end{array}$ & $\begin{array}{l}\text { Ulama, pekerja seni, } \\
\text { pedagang sayur, ikan } \\
\text { dan daging di pasar, } \\
\text { serta kuliner/makanan } \\
\text { khas, PNS }\end{array}$ \\
\hline Hak Kepemilikan & Dominasi Hak Milik & Dominasi Hak Waris & $\begin{array}{l}\text { Dominasi Hak } \\
\text { Penyewa }\end{array}$ & Dominasi Hak Milik \\
\hline
\end{tabular}

Sumber: Olah Data, 2014 


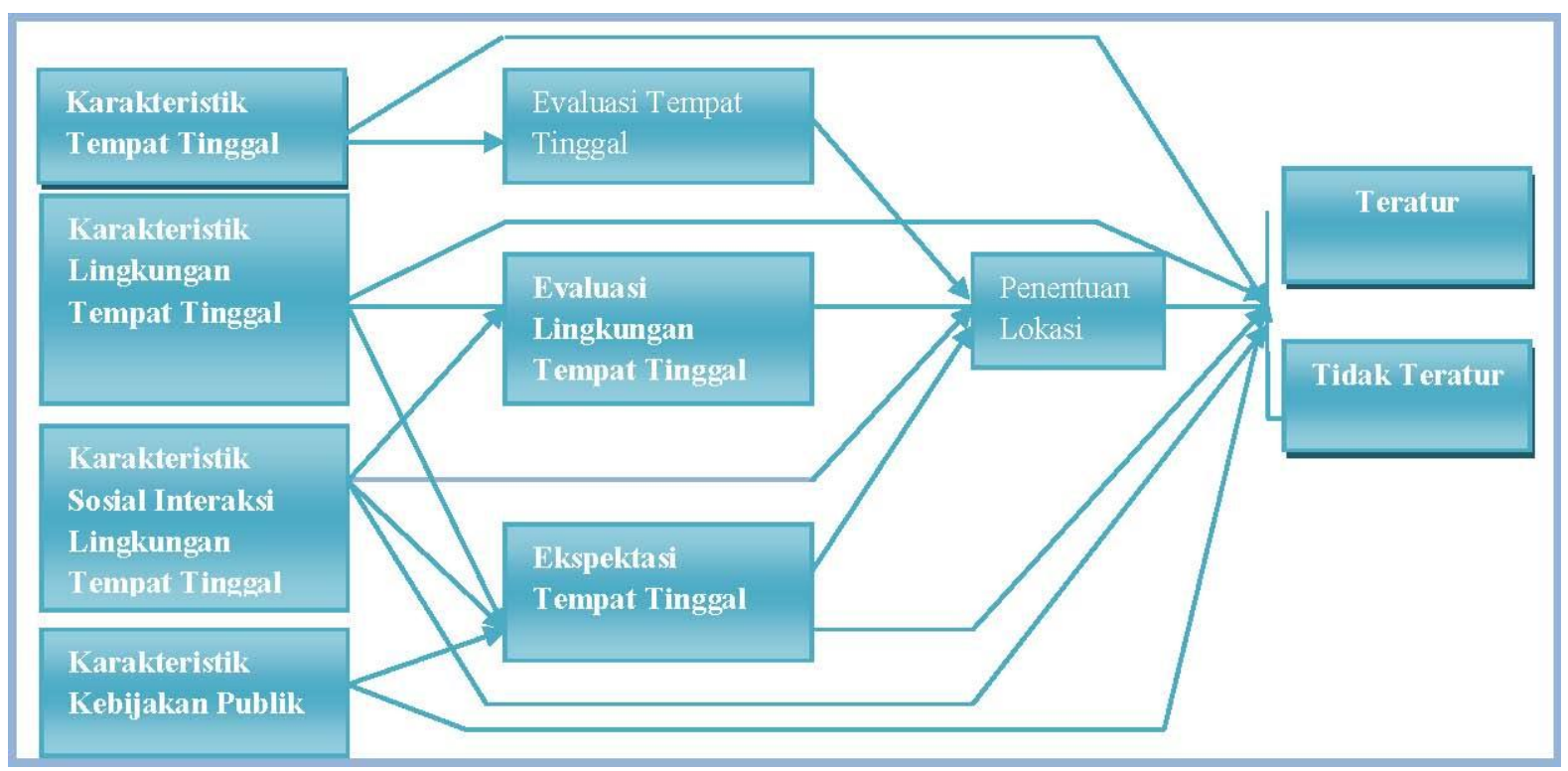

Gambar 3. Faktor-Faktor yang Berpengaruh terhadap Pola Perumahan Menurut Etnis di Kuto Batu Berdasar Konsep Galster (1987)

Sumber: Olah Data, 2014

Karakteristik interaksi sosial lingkungan tempat tinggal adalah kondisi sistem bermasyarakat di sekitar lingkungan tempat tinggal baik yang bersifat percampuran, kerjasama, ataupun persaingan. Hasil observasi menunjukan terdapat interaksi sosial yang dinamis dari kelompok etnis dalam rangka penyelengaraan kehidupan di Kelurahan Kuto Batu. Secara umum, kekompakan dari masyarakat di Kuto Batu cukup baik, hal ini terlihat dari partisipasi mereka ketika peneliti melakukan kegiatan pemetaan partisipatif dimana hampir semua ketua RT dan atau perwakilannya terlibat dalam kegiatan ini. Interaksi di lingkungan Kuto Batu dari masing-masing kelompok etnis terwujud juga dalam kuliner. Hal ini tampak dari keseharian masyarakat dalam mengkonsumsi lauk pauk dan makanan ringan. Interaksi sosial juga bersifat disosiatif. Sejauh ini untuk pertentangan dan konflik tidak ditemukan baik pada catatan laporan kriminalitias di pemerintahan kelurahan maupun dari konfirmasi kepada masyarakat di lingkungan Kuto Batu, sedangkan untuk persaingan dalam hal positif dapat ditemui di kelurahan ini. Persaingan yang muncul lebih kepada motif ekonomi sebagai fungsi adaptasi kelompok etnis pada tuntutan hidup.

Kebijakan publik adalah pertimbangan terhadap ruang gerak di sekitar lingkungan tempat tinggal yang berkaitan dengan kemudahan untuk akses tempat tinggal tersebut. Awalnya kebijakan permukiman di daerah ini terorganisasi berdasarkan ras dan klas. Akan tetapi seiring waktu, arahan tersebut telah luntur dengan meningkatnya jumlah penduduk pada awal kemerdekaan mendorong kebutuhan perumahan yang sangat tinggi. Sementara, ketersediaan bangunan perumahan masih sangat minim di kota ini. Pada saat itu pemerintah tidak lagi memikirkan untuk menyediakan rumah berdasar golongan tertentu tapi lebih kepada menjawab tantangan kebutuhan perumahan akibat adanya bangkitan dari perluasan jalan ke utara kota. Maka dari itu akses terhadap lokasi tidak terbatasi oleh kebijakan tertentu tetapi lebih kepada daya beli masyarakat terhadap lokasi. sehingga lokasi-lokasi strategis dapat dikuasi oleh etnis yang memiliki peranan ekonomi cukup tinggi di Kuto Batu yakni Tionghoa dengan terlihatnya lokasi ruko mereka berada di sepanjang jalan utama, sedangkan etnis selain lebih menyebar tetapi tetap membentuk kelompokkelompok kecil diantara lingkungan masyarakat Kuto Batu

Temuan-temuan tersebut menjadi dasar bagi pemerhati permasalahan kota khususnya dibidang permukiman dan perumahan dalam rangka merespon fenomena heterogenitas penduduk secara horisontal. Ketepatan arahan pembangunan dengan memperhatikan potensi dan permasalahan yang di wilayah menjadi kunci untuk mewujudkan pembangunan yang berkelanjutan. Perhatian terhadap komposisi penduduk yang plural perlu direspon oleh pemerintahan kota dalam rangka mewujudkan harmonisasi didalam penyelenggaran hidup.

Selain itu, adanya variasi pola sebaran ini juga dapat mempengaruhi dinamika perkotaan baik yang bersifat menguntungkan maupun merugikan kota. Respon yang tepat dan akurat pada fenomena ini perlu diperhatikan terutama terhadap peluang-peluang 
terhadap faktor-faktor yang mempengaruhi terbentuknya variasi sebaran perumahan menurut kelompok etnis. Saran akhir dari penelitian ini adalah agar pemerintah dan masyarakat saling berpartisipasi untuk mewujudkan masa depan kota yang lebih mengenal jati diri kota itu sendiri sehingga perencanaan kota yang melibatkan masyarakat akan lebih dapat dirasakan langsung baik bagi pemerintah maupun masyarakat setempat.

\section{KESIMPULAN}

1. Pola sebaran perumahan menurut kelompok etnis di Kelurahan Kuto Batu menujukkan variasi sebaran yang khas antara lain: a) sebaran perumahan etnis Tionghoa berpola teratur dimana tersusun berderet mengikuti geometri jaringan jalan sehingga pola bentuk sebarannya seperti huruf L dan I. b) sebaran perumahan etnis Arab berpola tidak teratur. Susunan bangunan perumahan etnis Arab memiliki kesan semu yang seolah-olah tersusun memusat pada obyek/fasilitas umum seperti lapangan, tempat ibadah, bahkan situs kuna (Rumah Batu). Geometri dari susunan bangunan perumahan berhadap-hadapan dan memusat pada obyek khusus menciptakan pola bentuk seperti huruf U dan I. c) sebaran perumahan etnis Jawa berpola tidak teratur. Memusat di sekitar lokasi tempat bekerja dengan akses harga rumah yang relatif murah (dekat sungai). Orientasi dari bangunan perumahan etnis Jawa adalah membelakangi sungai sehingga bentuk dari perumahan mereka terkesan menciptakan pola bentuk seperti huruf $S$ dan I. d) sebaran dari perumahan etnis Melayu berpola tidak teratur. Susunan bangunan perumahan pada tiap zona bervariasi sehingga memiliki kesan kombinasi/ percampuran dari susunan berderet dan memusat.
Orientasi bangunan perumahan menghadap ke arah daratan. Geometri dari bentuk bangunan perumahannya pada tiap zona juga teridentifikasi sebagai percampuran antara bentuk L, I, U, dan S.

2. Faktor-faktor yang mempengaruhi pola sebaran perumahan menurut kelompok etnis di Kelurahan Kuto Batu antara lain adalah kecenderungan dalam mempertimbangkan lokasi perumahan berdasarkan kriteria dari karakter tempat tinggal, karakter lingkungan tempat tinggal, interkasi sosial serta kebijakan publik yang berlaku di lingkungan tersebut.

\section{DAFTAR PUSTAKA}

CLIP. (2007). Housing and Integration of Migrants in Europe. Council of Europe.

Deurloo, M.C., \& Musterd, S. (2001). Residential Profiles of Surinamese and Moroccans in Amsterdam. Urban Studies. 38(3).

Galster, G. (1987). Homeowners and Neighborhood Reinvestment. Durham. Duke University Press.

Massey, D \& Denton, N. 1988. The Dimensions of Residential Segregation. Social Forces. 67(2), 281315.

Musterd. Sako. (2011). The Impact Of Immigrations Segregation And Concentration On Social Integration In Selected European Contexts. Journal Documents d'Analisis Geografica 2011. 57(3).

Reardon, S. F., \& O'Sullivan, D. (2004). Measuring of Spatial Segregation. Sociological Methodology. 34, 121-162.

Saltman, J. (1991). Theoritical Orientation: Residential Segregation. In E. D. Huttman (Ed.). Urban Housing Segregation of Minorities in Western Europe and The United States. Durham. Duke University Press. 